\title{
Research of the Energy Losses of Photovoltaic (PV) Modules after Hail Simulation Using a Newly-Created Testbed
}

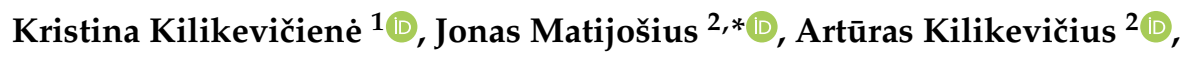 \\ Mindaugas Jurevičius ${ }^{1}$, Vytautas Makarskas ${ }^{1}$, Jacek Caban ${ }^{3}$ and Andrzej Marczuk ${ }^{3}$ \\ 1 Department of Mechanical and Material Engineering, Vilnius Gediminas Technical University, J. \\ Basanaviciaus St. 28, LT-03224 Vilnius, Lithuania; kristina.kilikeviciene@vgtu.lt (K.K.); \\ mindaugas.jurevicius@vgtu.lt (M.J.); vytautas.makarskas@vgtu.lt (V.M.) \\ 2 Institute of Mechanical Science, Vilnius Gediminas Technical University, J. Basanaviciaus St. 28, LT-03224 \\ Vilnius, Lithuania; arturas.kilikevicius@vgtu.lt \\ 3 Department of Agricultural, Forestry and Transport Machines, University of Life Sciences in Lublin, 28 \\ Głęboka Street, 20-612 Lublin, Poland; jacek.caban@up.lublin.pl (J.C.); andrzej.marczuk@up.lublin.pl (A.M.) \\ * Correspondence: jonas.matijosius@vgtu.lt; Tel.: +370-684-04-169
}

Received: 23 October 2019; Accepted: 26 November 2019; Published: 28 November 2019

\begin{abstract}
The impact of hail ice cubes on composite structures (such as solar cells) causes actual defects. This article presents a series of tests, in which solar cell modules were exposed to hail simulation testbed balls, allowing to assess the following: the impact energy, which causes the major defects in solar cells; the formed micro-cracks in the structure of solar cells, resulting in the loss of power generated by a solar cell; and the solar cell parameters necessary for modelling. In addition, this article presents a digital analysis of hail simulation. Information received from the digital analysis was used to optimize the structure of solar cells in order to improve its resistance properties. The aim of this study was to present a simple method for experimental hail simulation. The proposed hail impact estimation method can be successfully applied to study the influence of the mechanical-dynamic impact of photovoltaic (PV) modules of different structures on the technical characteristics of these modules (structural stability, power generation, etc.). The study showed that PV modules are subjected to an irreversible effect of the excitation force (i.e., micro-cracking) and it can reduce the generated power by $2.33 \%$ to $4.83 \%$.
\end{abstract}

Keywords: photovoltaic (PV) module; hail simulation; resistance of photovoltaic modules; energy losses; newly-created testbed

\section{Introduction}

The operation and maintenance of photovoltaic (PV) power-generating modules have become increasingly more important in recent years, as the number of such modules is being raised to ensure maximum power generation throughout their life cycle. All types of degradations and failures adversely affect the reliability and lifetime of PV module installations. Analysis of the impact of these factors on technical and financial problems is becoming more important for operators and investors [1]. PV electricity generation has become an important factor in the electricity mix in many countries and is expected to become even more important in the future [2]. PV failures have a significant impact on the safety, reliability, and energy balance of PV devices [3]. Similarly, malfunctions directly result in loss of power, which reduces the return on investment. The manufacturing process of PV modules from silicon solar cells is conventionally performed by soldering copper strips to the solder and metallizing the contact area. Contact shooting and screen printing are used for this purpose [4]. 
PV modules are either composites or laminates made up of different layers with very different mechanical properties and functions. Some layers of photovoltaic modules are designed to generate electricity, while others protect the modules from environmental effects. Two types of photovoltaic modules are usually used [5]: (1) rigid plates with glass layers on the outside to ensure the rigidity and protection of the modules from mechanical loads; (2) semi-flexible plates that must be fixed to flat or curved surfaces with a protective polymer layer, which allows the PV module to have some flexibility. Since PV modules are installed outdoors, thermo-hygrometric cycles, wind gusts, snow, and hail are the main sources of damage and degradation over the estimated 25 years of operation. To determine whether the solar cell and mechanical stresses exceed the permissible stress levels, several studies used the Finite Element Method (FEM) [4]. Beinert et al. analyzed mechanical stresses in frame-based and non-composite PV modules, where mechanical stresses were induced [6]. Other studies focused on determining the influence of joints [7] and their coating, mechanical properties [8], and geometry [4] on the mechanical stresses of PV modules. Mechanical impacts are among the factors most affecting the reliability and rigidity of PV modules [8-10]. Their impact on durability and electrical operation of PV modules were reviewed [11-18]. When it comes to mechanical impacts, the impact of hail on PV modules is significant, as it may result in the breakdown of silicon, which in turn may lead to significant electricity loss. Hail tests are usually carried out using pneumatic equipment (the diameter of an ice cube is $25 \mathrm{~mm}$ and its speed at impact reaches $23 \mathrm{~m} / \mathrm{s}$ ) and by analyzing the curves of electrical current losses from the current voltage (I-V), as well as the electroluminescence pictures that allow clear visual identification of micro-cracks and their impact on electrical response [19-21].

All newly-manufactured PV modules in Europe, regardless of their type, must meet the requirements of the International Electrotechnical Commission (IEC) 61215 standards [22]. The IEC also defines hail impact simulation tests which must be performed by firing a formed ice ball on a PV module, using a pneumatic actuator [23]. The standard IEC 61215 defines an ice ball diameter of $25 \mathrm{~mm}$ and an impact velocity of $23 \mathrm{~m} / \mathrm{s}$. However, during a hail, the parameters (the shape and size) and impact velocity of the ice balls vary, therefore the test aims to assess whether the PV module itself can withstand the hail.

It is very important that the correlation between impact velocity and the diameter of the ice ball is determined based on the requirements of IEC 61215. On the other hand, the repeatability of the tests is important in the test process too. This is very difficult to ensure because the ice balls used must have the correct shape and no cracks or other defects that will affect the test results $[24,25]$. Thus, the preliminary series of shots we used allowed us to identify and select the most appropriate impact velocity and use it during the tests.

The research methodology applied in this work allowed to simplify the test procedure and to ensure its repeatability by using a $40 \mathrm{~mm}$ diameter sphere instead of an ice ball (the material of the sphere was also selected similar in density to the ice ball). Therefore, the requirements of the IEC standards did not need to be applied, since the conversion of the linear velocity of the ice ball to obtain the same impulse was not applied.

Carrying out the theoretical research of the problem is important in order to supplement experimental research. The problem of impact and contact mechanics in the dynamics has been extensively studied from both the experimental and theoretical perspectives, but most studies addressed the problems concerning the aerospace and defense fields [26,27]. In the aforementioned research, composite cellular plates $[28,29]$ dominated as the main subject. This article analyzes the possibilities and challenges of the newly-created testbed for hail simulation, for which the market demand is very high-especially in small and medium-sized enterprises-and which in turn determines the cost of new technologies $[30,31]$. The newly-developed testbed allows achieving the parameters used in similar research (ball speed and the impact force) [11]. Most studies simulate the effects of hail using pneumatic equipment that provides the energy needed to move a piece of ice [2,4,32-36]. The hail test requires expensive, time-consuming equipment. Thus, one of the main aims of this study was to provide a simple method for experimental hail simulation. The proposed hail impact estimation 
methodology can be successfully applied to study the influence of the mechanical-dynamic impact of PV modules of different structures on the technical characteristics of these modules (structural stability, power generation, etc.) [37-53]. This study employed a newly-developed hail simulation bench, which allows the value of the impact force applied to the PV module to be varied and the angle of the action of that force to be adjusted. The ability to change and adjust the action angle brings the experiment closer to the real conditions of the PV module since the PV modules are almost always angled. The paper investigates the potential of the newly-developed bench and assesses the impact of different forces acting on the PV module on the technical characteristics of that module.

\section{Hail Simulation Testbed and Equipment for Measuring Dynamic Parameters}

The subject of this research was the newly-created hail simulation testbed (see Figure 1). The testbed consisted of three parts: the hail simulation part, the part for measuring acceleration and force, and the part for detecting defects of solar cells (electroluminescence). The hail simulation part consisted of a motor with a frequency converter, hail simulation components, and a solar module moving on rails. The part for measuring acceleration and force parameters comprised force and acceleration sensors and equipment for processing and storing measurement results. The part for detecting the defects of the PV module consisted of a camera and equipment for processing and storing results. The specifics of the PV module chosen for this research: cell size $37 \times 156 \mathrm{~mm}$; number of cells 10; front-side $3.2 \mathrm{~mm}$ hardened solar glass; dimensions $(\mathrm{L} \times \mathrm{W}) 322 \times 204 \mathrm{~mm}$; weight $625 \mathrm{~g}$. This type of a PV module is commonly used as a roof tile. The PV module consisted of: 3.2-mm non-iron glass/EVA film $(0.4 \mathrm{~mm}) /$ The matrix of PV modules/EVA film/PPE plastic.

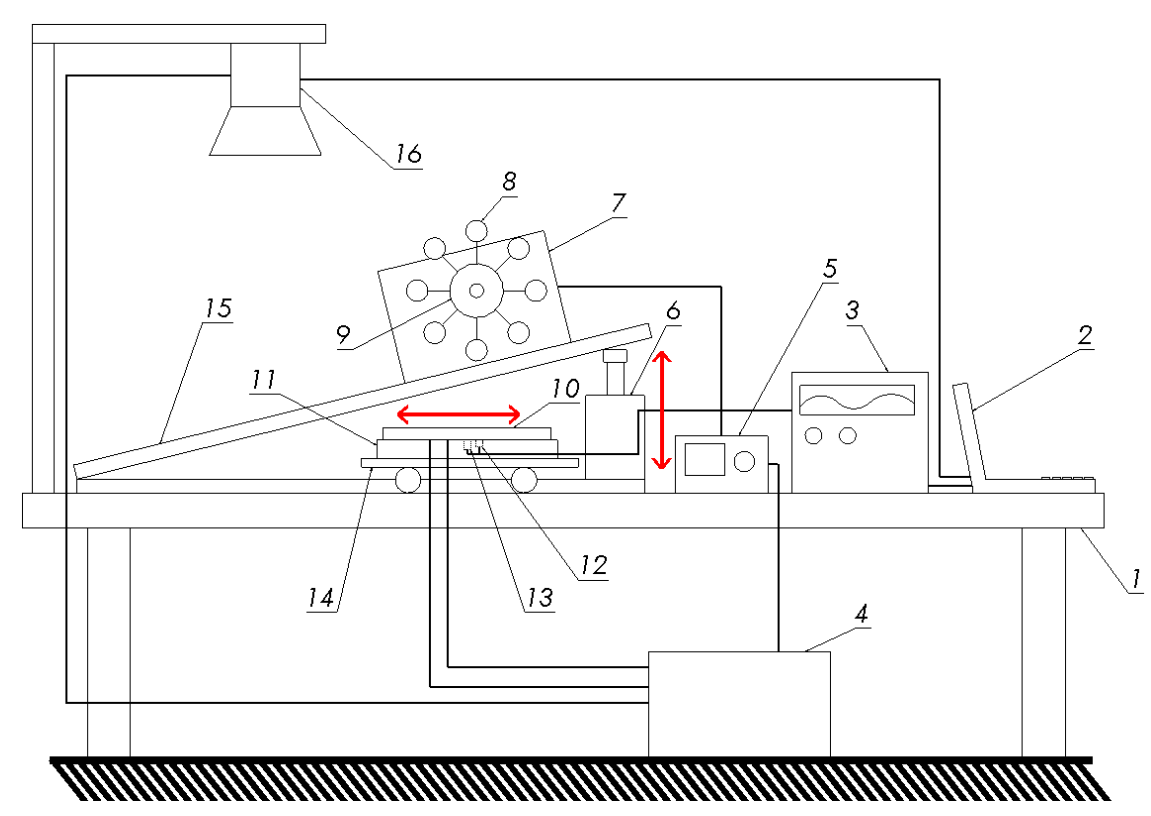

(a)

Figure 1. Cont. 


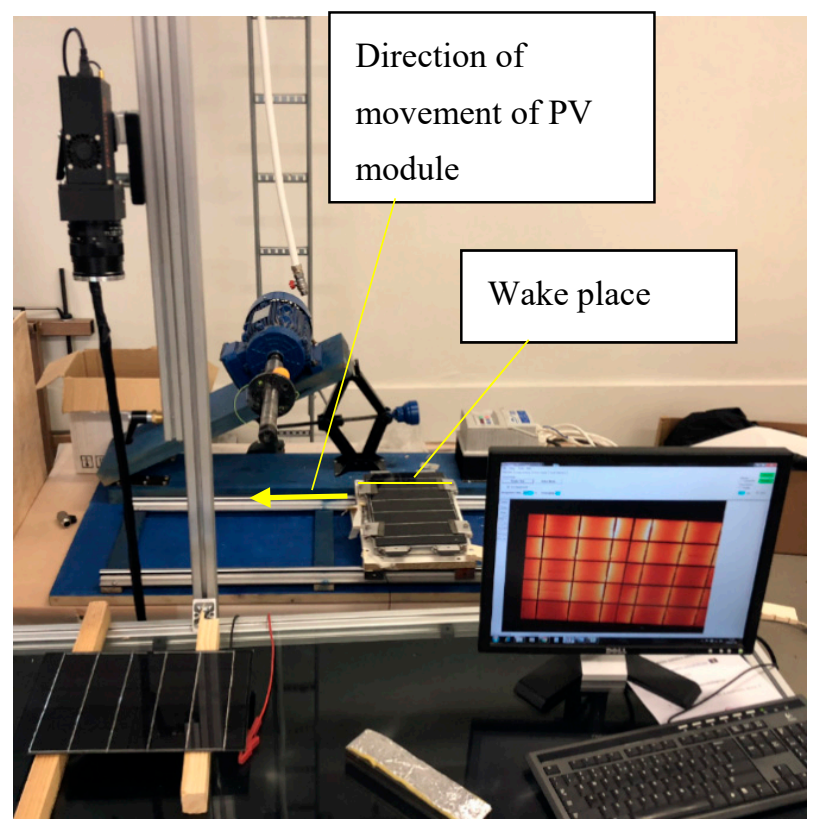

Figure 1. Scheme of the photovoltaic (PV) module testbed (a) and general view (b). In (a): where: 1-a table, 2-a computer, 3-data processing and storage equipment, 4-a generator, 5-a control unit, 6-lifting equipment, 7-a motor, 8-balls (material-PPE plastic), 9-a bushing, 10—a PV module, 11-a frame, 12-a force transducer, 13 - an accelerometer, 14-a carriage, 15-a portable base, 16-an electroluminescent stand (Greateyes GE 10241024 BI MID CCD camera; NIR (near-infrared) spectrum: 780-1,100 nm). The Brüel \& Kjær meters were used to measure oscillations and force parameters (see Figure 2): (1) portable equipment for processing, storing and managing measurement results Machine Diagnostics Toolbox-Type 9727; (2) a single-axis accelerometer 8341; (3) a force transducer 8230.

The aims of the study were to find out the possibilities of the newly-created testbed, to perform hail simulation tests, and to determine the impact of dynamic effects on the structure and performance of PV modules. During the experiment, the rotational speed was changed to simulate dynamic mechanical loads that correspond to different speeds of ice cubes during hail. The PV module was firmly attached to the carriage that moved on the rail. The motor pushed the mechanism with fastening balls, which excited PV modules. The motor was connected to the control unit, which controlled frequencies (in the 5-60 Hz range) and revolutions. The accelerometer was affixed to the centre of the PV module, at the bottom, in order to measure the values and nature of the incoming signal (acceleration and displacement). The force transducer designated for measuring ball impacts was affixed next to the accelerometer. The accelerometer and the force transducer were connected to data storage and processing equipment. The data storage and processing equipment were connected to the computer, which graphically displayed the results. Before and after the hail simulation, PV modules were photographed (using an electroluminescence camera) on the electroluminescent stand with an electric current (the current depended on the size of the PV modules; it can reach up to 4-5 A) supplied to the PV modules. Electroluminescent imaging is usually used to check for defects [54-56] because the intensity of radiation is proportional to the current density. The pictures taken helped detect any defects in the PV modules.

Figure 2 illustrates the block diagram of the testbed. 


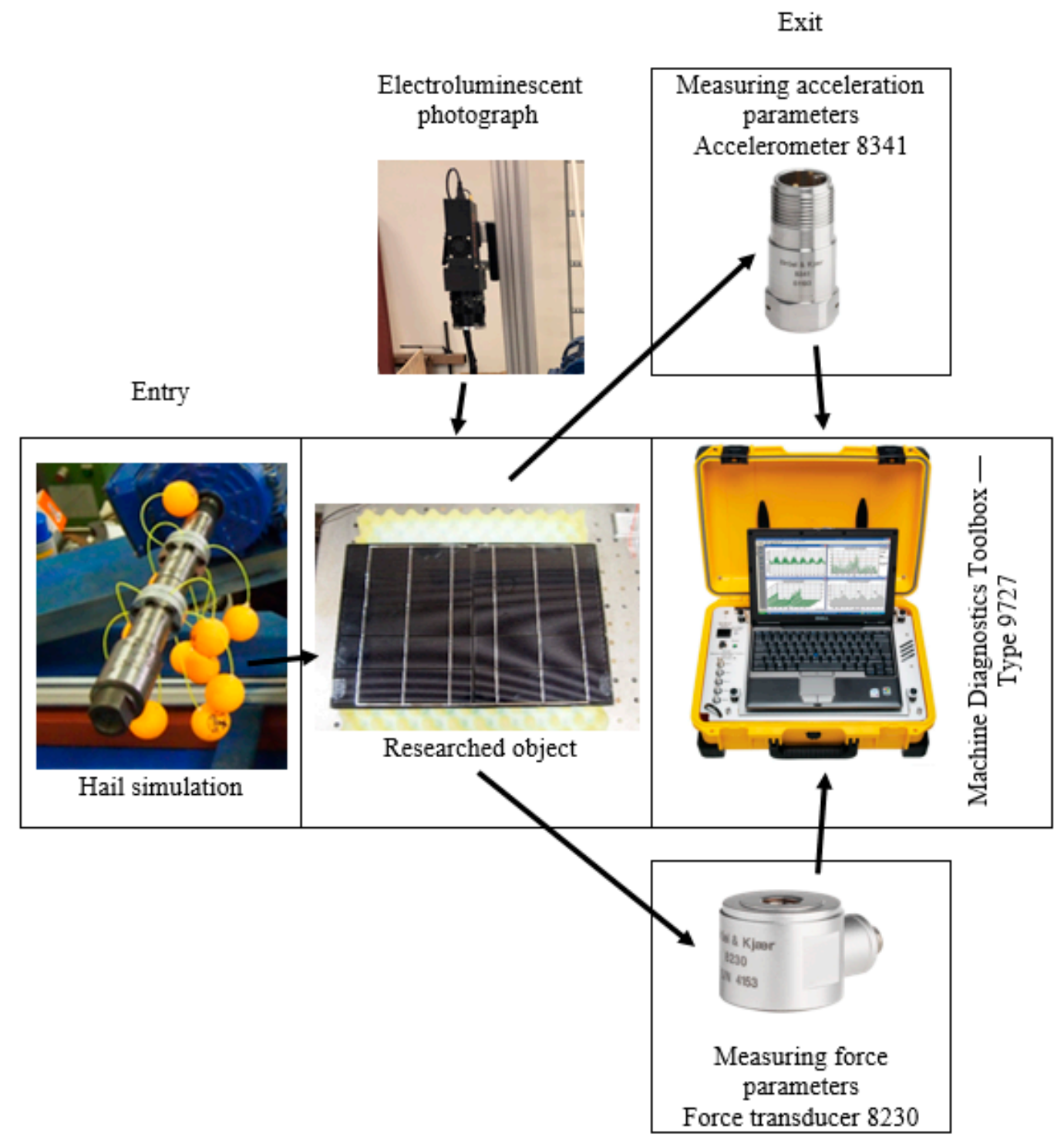

Figure 2. Block diagram of the dynamic mechanical load-generating facility.

\section{Experimental and Theoretical Research Results}

The first stage of the experimental research was aimed at finding out the necessary force that creates cracks in PV modules. The excitation force affecting PV modules was gradually increased (see the first peak in Figure 3) during the first stage, which was done by changing the speed of engine rotations (see position 7, Figure 1a). In the second stage, after the force required to create cracks was determined, a number of tests was carried out to assess the regularities of the cracks. The force and acceleration were measured during the tests. Figure 3 shows the acceleration values. The aim of the tests was to determine the frequency characteristics of the PV module. 


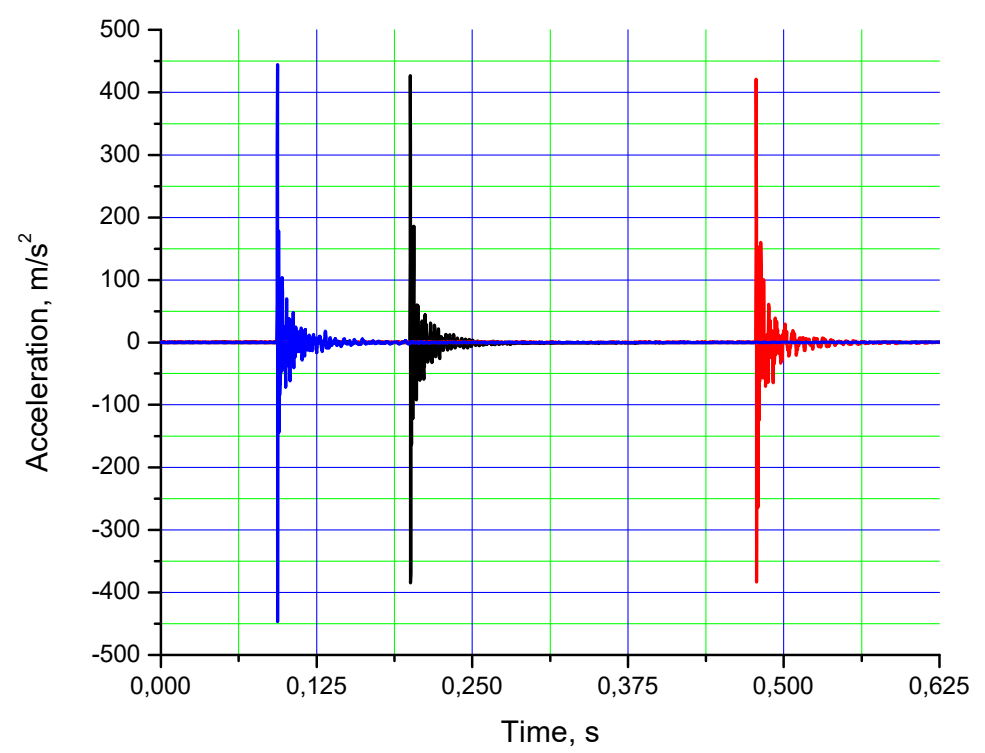

(a)

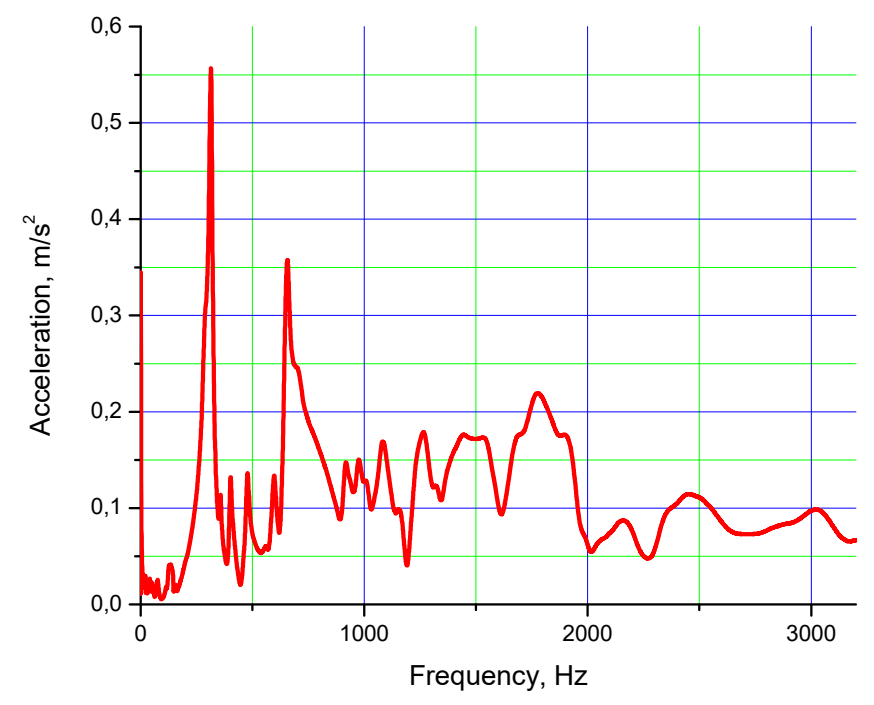

(b)

Figure 3. PV module acceleration (a) and its spectral density (b) (results of three tests and the average spectral density curve).

The analysis of the first-stage results (see Figure 4) revealed that internal cracks in the PV module formed at the force of $582.06 \mathrm{~N}$, and glass cracks appeared at the force of $1129 \mathrm{~N}$. After the interaction, a visual PV module inspection was performed to check for any cracks. The tests of the second stage aimed to maintain similar forces. 


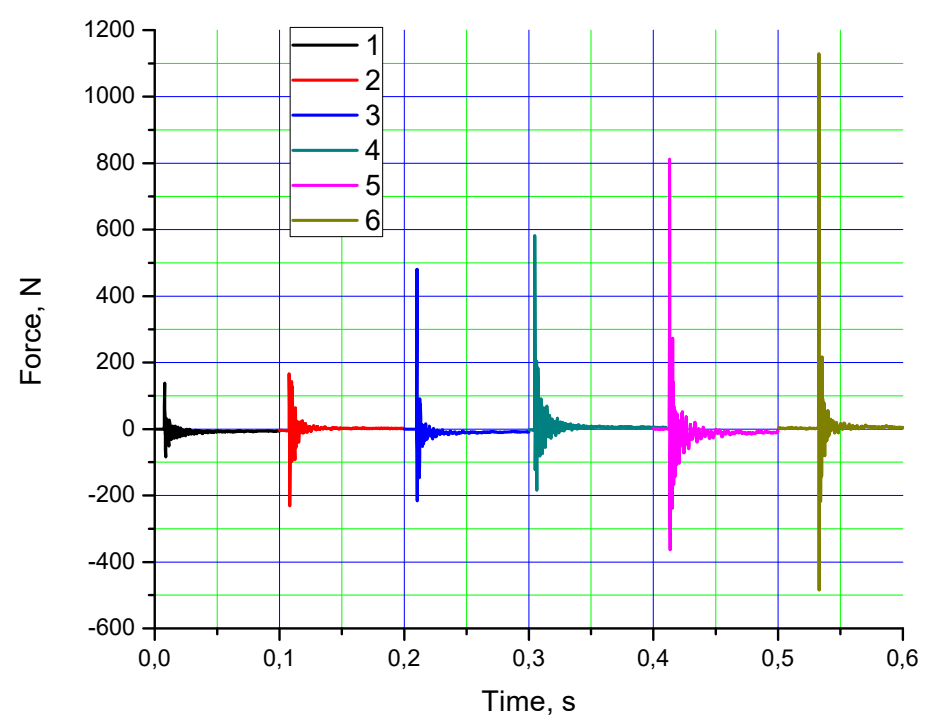

(a)
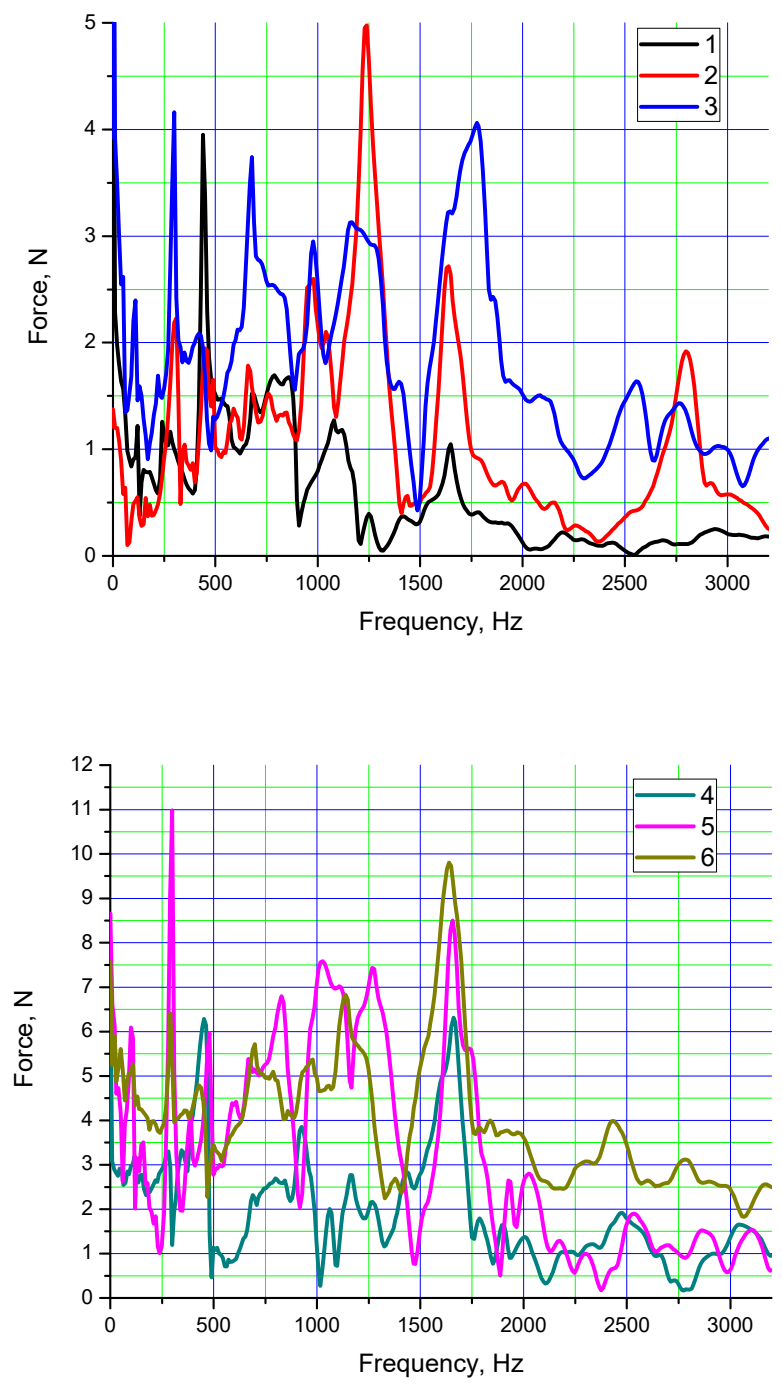

(b)

Figure 4. The force which the PV module is exposed to (a) and its spectral density (b) (black-137.92 N; red-166.07 N; blue-480.81 N; green-582.06 N; pink—811.9 N; dark yellow-1129 N). 


\section{Research of the Resistance of Photovoltaic Modules}

Solar cell cracks and their regularities were analyzed in the second stage of the experimental tests. The purpose of these tests was to find and identify defects (e.g., cracks) in the PV modules, in their glass and their interior structure. In order to compare the main parameters of the PV module after the impact of the hail testbed, the PV module was photographed with the electroluminescent stand at the beginning of the study and measured using a voltaic characteristic of the testing stand. First damage, marked in yellow, was observed at the force of hail simulation balls of $582.06 \mathrm{~N}$ (The middle image of PV module 1 in Table 1). An electroluminescent photo of the test at the force of 1129 $\mathrm{N}$ can be seen on the right side of Table 1. The electroluminescent photo of the test at the force of 1129 $\mathrm{N}$ was presented accordingly; the majority of defects, which are marked in yellow, formed during this test. More findings have been presented in previous studies [14]. A uniform excitation force was maintained during the test; the force was selected in accordance with a previous study which found that the first cracks in the PV module occurred at a force of $582.06 \mathrm{~N}$. The weight of the hail imaging ball used in the experiment was $30 \mathrm{~g}$; diameter $40 \mathrm{~mm}$; movement speed $27.5 \mathrm{~m} / \mathrm{s}$; and energy 11.1 $\mathrm{J}$ (these parameters corresponded to the values recommended in IEC 61215). More features of the stand are described in the article [11]. During the experiment, one ball was used and the PV module was uniformly moved from right to left (see Figure 1b); the PV modules were excited one by one in 4 strokes. The PV module was excited along the middle section (see Figure 1b).

Table 1 was compiled out of the two drafted voltaic data (before the tests and after the sixth test). It compares the three key parameters: the generated power $(\mathrm{W})$, the maximum voltage $(\mathrm{V})$, and the maximum current (A). Table 1 shows the characteristics of the PV module 1 after the test at $1129 \mathrm{~N}$. In Table 1, the characteristics of PV modules were obtained using I-V (Voltage Amps) measuring equipment: Pasan Highlight 3, class AAA+, measuring time $10 \pm 1 \mathrm{~ms}$. Measured under standard conditions: $1000 \pm 30 \mathrm{~W} / \mathrm{m}^{2}$, solar spectrum AM $1.5 \mathrm{~g}, 25^{\circ} \mathrm{C}$ [57-60].

Table 1. Changes in performance characteristics of PV cells after the hail simulation test.

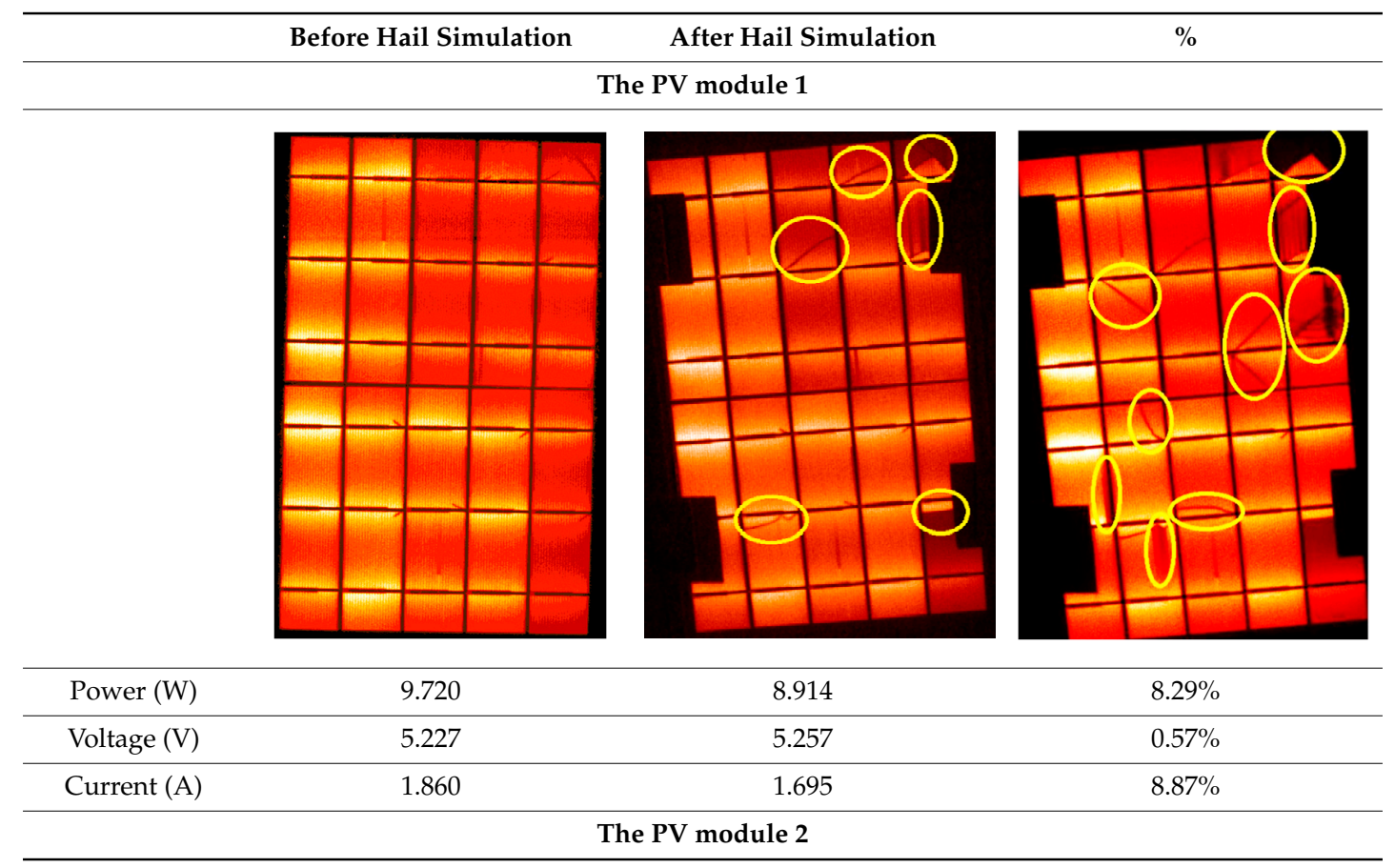


Table 1. Cont.

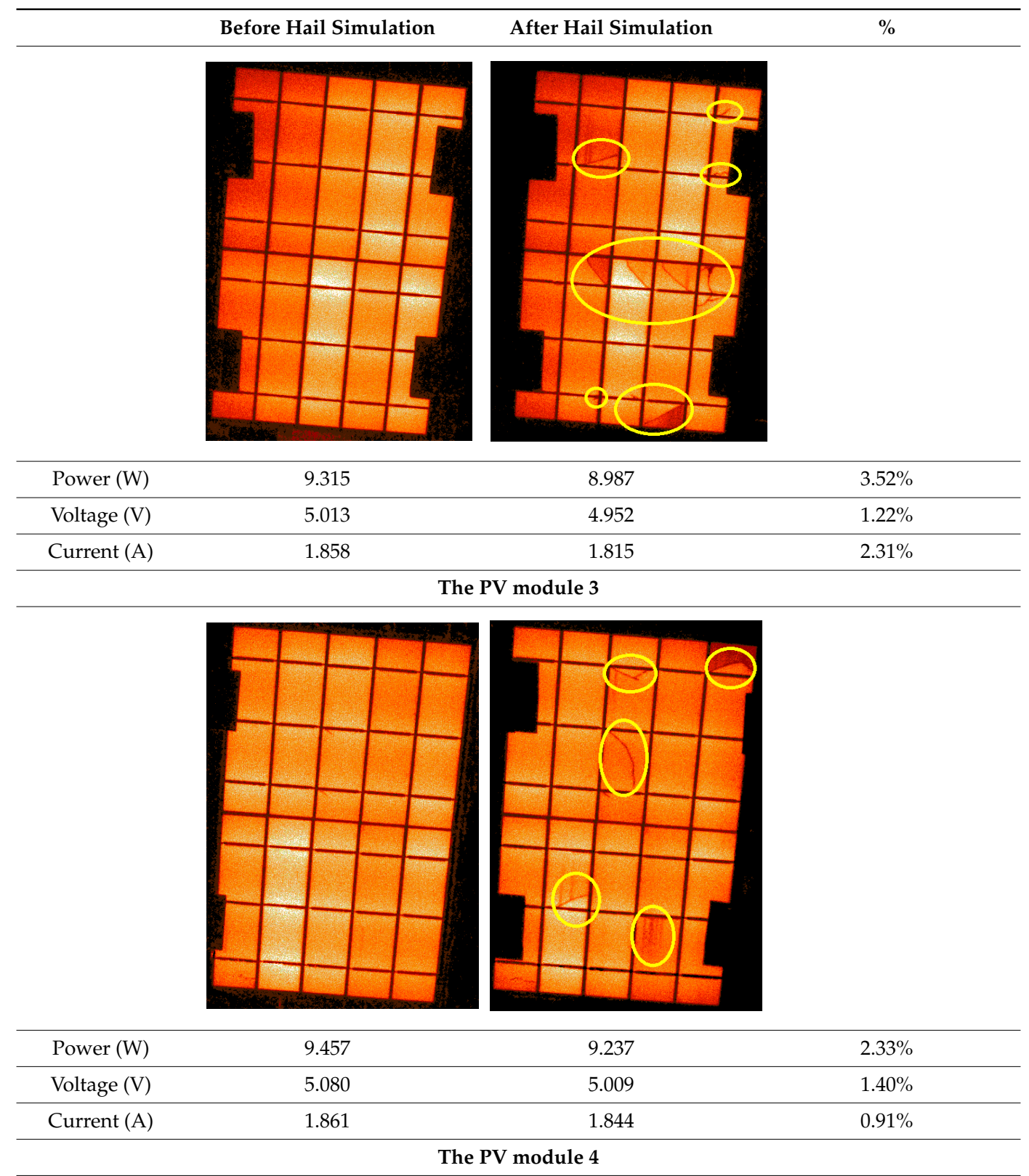
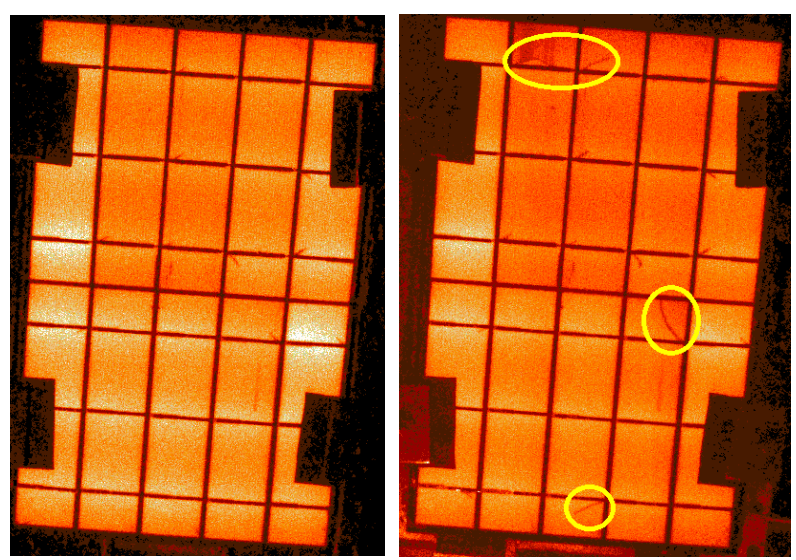
Table 1. Cont.

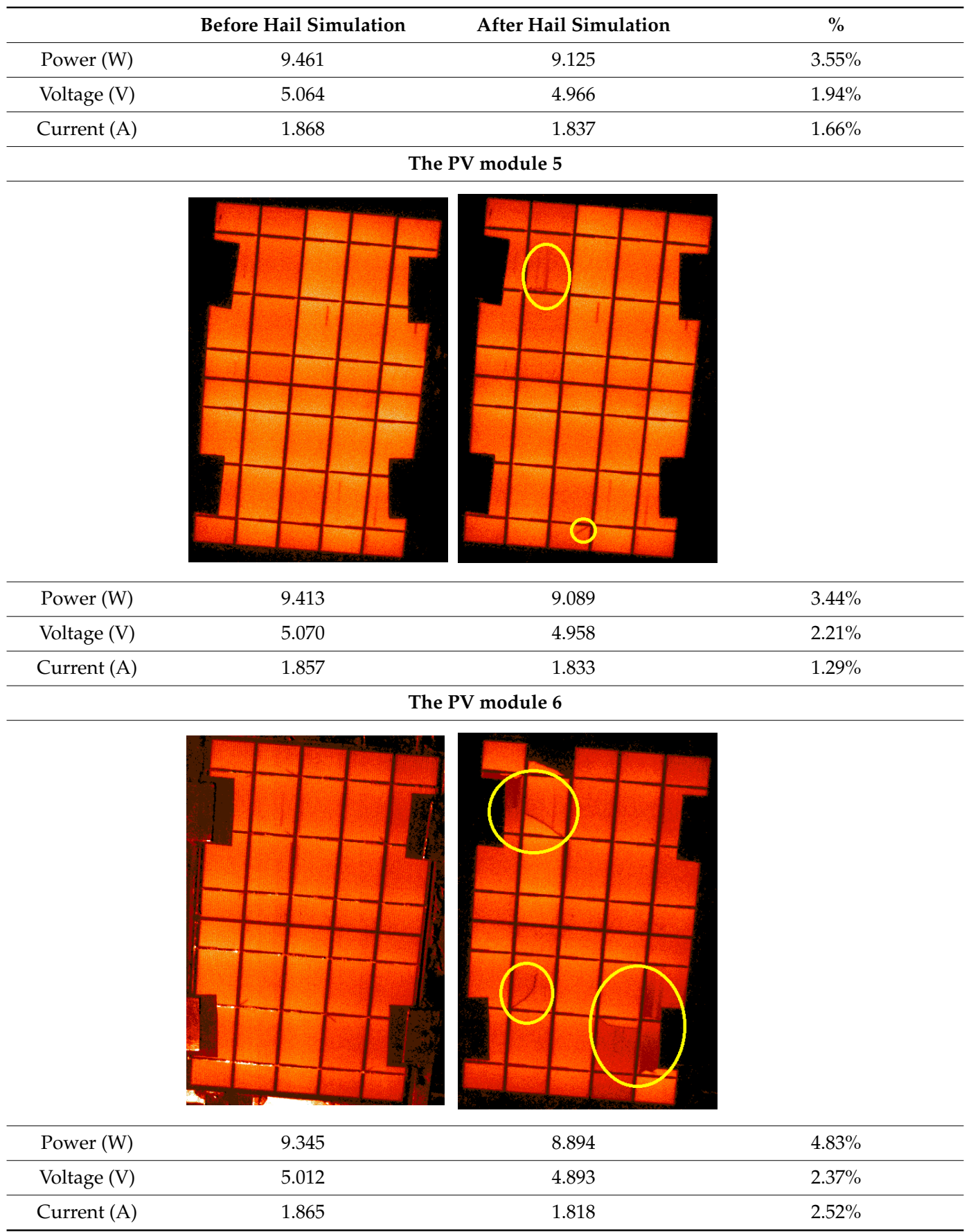

The analysis of the results received (Table 1) revealed that micro-cracks mainly formed at the point of contact between the solar cell and the ball simulating an ice cube, and some micro-cracks appeared at the fastening points on the edges of the PV module. When it comes to power losses, the analysis of the results of Table 1 showed a loss of power ranging from $2.33 \%$ to $4.83 \%$ when the impact of the force-induced micro-cracking (i.e., the magnitude of the force) was assessed. Accordingly, the assessment of the impact of the maximum force $(1129 \mathrm{~N})$ used in the research showed that the loss of power was $8.29 \%$ and that a force, having increased twice, leads to a loss of power of 1.7 to 3.56 times. In summary, the researched solar modules suffered significant damage after the hail simulation test. The structure of the PV modules was mechanically damaged (cracks formed), resulting in a loss of power. 


\section{Conclusions}

The present study examined a newly-created hail simulation testbed aimed at identifying the necessary conditions for hail simulation and assessing the performance parameters of PV modules before and after the dynamic impact.

After the hail simulation test, the tested PV modules suffered severe damage, resulting in cracks in their crystalline structure and the loss of generated power.

The conducted tests revealed that micro-cracks in the crystalline structure of the PV module formed when the module was exposed to the force. When the PV module was exposed to the said force, the generated power losses ranged from $2.33 \%$ to $4.83 \%$. After increasing the force impacting the PV module, power loss increased to $8.29 \%$.

Author Contributions: For research articles with several authors, a short paragraph specifying their individual contributions must be provided. The following statements should be used "conceptualization, K.K. and J.M.; methodology, A.K.; software, M.J.; validation, V.M., J.C. and A.M.; formal analysis, K.K.; investigation, J.M.; resources, A.K.; data curation, M.J.; writing—original draft preparation, V.M.; writing—review and editing, J.C.; visualization, A.M.; supervision, A.K.; project administration, J.M.

Funding: This research received no external funding.

Conflicts of Interest: The authors declare no conflict of interest.

\section{References}

1. Buerhop, C.; Wirsching, S.; Bemm, A.; Pickel, T.; Hohmann, P.; Nieß, M.; Vodermayer, C.; Huber, A.; Glück, B.; Mergheim, J.; et al. Evolution of cell cracks in PV-modules under field and laboratory conditions. Prog. Photovolt. Res. Appl. 2018, 26, 261-272. [CrossRef]

2. Camus, C.; Offermann, P.; Weissmann, M.; Buerhop, C.; Hauch, J.; Brabec, C.J. Site-specific assessment of mechanical loads on photovoltaic modules from meteorological reanalysis data. Sol. Energy 2019, 188, 1134-1145. [CrossRef]

3. Lillo-Bravo, I.; González-Martínez, P.; Larrañeta, M.; Guasumba-Codena, J. Impact of Energy Losses Due to Failures on Photovoltaic Plant Energy Balance. Energies 2018, 11, 363. [CrossRef]

4. Rendler, L.C.; Romer, P.; Beinert, A.J.; Walter, J.; Stecklum, S.; Kraft, A.; Eitner, U.; Wiese, S. Thermomechanical stress in solar cells: Contact pad modeling and reliability analysis. Sol. Energy Mater. Sol. Cells 2019, 196, 167-177. [CrossRef]

5. Corrado, M.; Infuso, A.; Paggi, M. Simulated hail impacts on flexible photovoltaic laminates: Testing and modelling. Meccanica 2017, 52, 1425-1439. [CrossRef]

6. Beinert, A.J.; Ebert, M.; Eitner, U.; Aktaa, J. Influence of Photovoltaic Module Mounting Systems on the Thermo-Mechanical Stresses in Solar Cells by FEM Modelling. In Proceedings of the 32nd European Photovoltaic Solar Energy Conference and Exhibition, Munich, Germany, 20-24 June 2016; pp. 1833-1836.

7. Tippabhotla, S.K.; Radchenko, I.; Song, W.J.R.; Illya, G.; Handara, V.; Kunz, M.; Tamura, N.; Tay, A.A.O.; Budiman, A.S. From cells to laminate: Probing and modeling residual stress evolution in thin silicon photovoltaic modules using synchrotron X-ray micro-diffraction experiments and finite element simulations: Probing and modeling residual stress evolution. Prog. Photovolt. Res. Appl. 2017, 25, 791-809. [CrossRef]

8. Višniakov, N.; Kilikevičius, A.; Novickij, J.; Grainys, A.; Novickij, V. Low-cost experimental facility for evaluation of the effect of dynamic mechanical loads on photovoltaic modules. Eksploat. Niezawodn. Maint. Reliab. 2015, 17, 334-337. [CrossRef]

9. Kilikevičius, A.; Čereška, A.; Kilikevičienè, K. Analysis of external dynamic loads influence to photovoltaic module structural performance. Eng. Fail. Anal. 2016, 66, 445-454. [CrossRef]

10. Martins, A.C.; Chapuis, V.; Virtuani, A.; Li, H.-Y.; Perret-Aebi, L.-E.; Ballif, C. Thermo-mechanical stability of lightweight glass-free photovoltaic modules based on a composite substrate. Sol. Energy Mater. Sol. Cells 2018, 187, 82-90. [CrossRef]

11. Kilikevičienè, K.; Matijošius, J.; Fursenko, A.; Kilikevičius, A. Tests of hail simulation and research of the resulting impact on the structural reliability of solar cells. Ekspolatacja Niezawodn. Maint. Reliab. 2019, 21, 275-281. [CrossRef] 
12. Paggi, M.; Corrado, M.; Berardone, I. A global/local approach for the prediction of the electric response of cracked solar cells in photovoltaic modules under the action of mechanical loads. Eng. Fract. Mech. 2016, 168, 40-57. [CrossRef]

13. Di Giacomo, F.; Fakharuddin, A.; Jose, R.; Brown, T.M. Progress, challenges and perspectives in flexible perovskite solar cells. Energy Environ. Sci. 2016, 9, 3007-3035. [CrossRef]

14. Said, S.A.M.; Hassan, G.; Walwil, H.M.; Al-Aqeeli, N. The effect of environmental factors and dust accumulation on photovoltaic modules and dust-accumulation mitigation strategies. Renew. Sustain. Energy Rev. 2018, 82, 743-760. [CrossRef]

15. Eisenträger, J.; Naumenko, K.; Altenbach, H.; Köppe, H. Application of the first-order shear deformation theory to the analysis of laminated glasses and photovoltaic panels. Int. J. Mech. Sci. 2015, 96, 163-171. [CrossRef]

16. Bouraiou, A.; Hamouda, M.; Chaker, A.; Mostefaoui, M.; Lachtar, S.; Sadok, M.; Boutasseta, N.; Othmani, M.; Issam, A. Analysis and evaluation of the impact of climatic conditions on the photovoltaic modules performance in the desert environment. Energy Convers. Manag. 2015, 106, 1345-1355. [CrossRef]

17. Ndiaye, A.; Kébé, C.M.F.; Charki, A.; Ndiaye, P.A.; Sambou, V.; Kobi, A. Degradation evaluation of crystalline-silicon photovoltaic modules after a few operation years in a tropical environment. Sol. Energy 2014, 103, 70-77. [CrossRef]

18. Kichou, S.; Silvestre, S.; Nofuentes, G.; Torres-Ramírez, M.; Chouder, A.; Guasch, D. Characterization of degradation and evaluation of model parameters of amorphous silicon photovoltaic modules under outdoor long term exposure. Energy 2016, 96, 231-241. [CrossRef]

19. Punge, H.J.; Kunz, M. Hail observations and hailstorm characteristics in Europe: A review. Atmospheric Res. 2016, 176-177, 159-184. [CrossRef]

20. Guo, B.; Javed, W.; Pett, C.; Wu, C.-Y.; Scheffe, J.R. Electrodynamic dust shield performance under simulated operating conditions for solar energy applications. Sol. Energy Mater. Sol. Cells 2018, 185, 80-85. [CrossRef]

21. Du, B.; Yang, R.; He, Y.; Wang, F.; Huang, S. Nondestructive inspection, testing and evaluation for Si-based, thin film and multi-junction solar cells: An overview. Renew. Sustain. Energy Rev. 2017, 78, 1117-1151. [CrossRef]

22. International Electrotechnical Commission. Technical Committee 82: Solar Photovoltaic Energy Systems. In Modules photovoltaïques (PV) au silicium cristallin pour application terrestre: Qualification de la conception et homologation = Crystalline Silicon Terrestrial Photovoltaic (PV) Modules: Design Qualification and Type Approval; International Electrotechnical Commission: Geneva, Switzerland, 2005; ISBN 978-2-8318-7963-5.

23. Kraemer, F.; Wiese, S.; Peter, E.; Seib, J. Mechanical problems of novel back contact solar modules. Microelectron. Reliab. 2013, 53, 1095-1100. [CrossRef]

24. Nikoletatos, J.; Halambalakis, G. Standards, Calibration, and Testing of PV Modules and Solar Cells. In McEvoy's Handbook of Photovoltaics; Elsevier: Chennai, India, 2018; pp. 1155-1182; ISBN 978-0-12-809921-6.

25. Osterwald, C.R. Standards, Calibration, and Testing of PV Modules and Solar Cells. In Practical Handbook of Photovoltaics; Elsevier: Waltham, MA, USA, 2012; pp. 1045-1069; ISBN 978-0-12-385934-1.

26. Perera, S.; Lam, N.; Pathirana, M.; Zhang, L.; Ruan, D.; Gad, E. Use of static tests for predicting damage to cladding panels caused by storm debris. J. Build. Eng. 2017, 12, 109-117. [CrossRef]

27. Pernas-Sánchez, J.; Artero-Guerrero, J.A.; López-Puente, J.; Varas, D. Numerical methodology to analyze the ice impact threat: Application to composite structures. Mater. Des. 2018, 141, 350-360. [CrossRef]

28. Sohel, K.M.A.; Richard Liew, J.Y.; Koh, C.G. Numerical modelling of lightweight Steel-Concrete-Steel sandwich composite beams subjected to impact. Thin Walled Struct. 2015, 94, 135-146. [CrossRef]

29. Zhang, D.; Fei, Q.; Zhang, P. Drop-weight impact behavior of honeycomb sandwich panels under a spherical impactor. Compos. Struct. 2017, 168, 633-645. [CrossRef]

30. Selech, J.; Joachimiak-Lechman, K.; Klos, Z.; Kulczycka, J.; Kurczewski, P. Life cycle thinking in small and medium enterprises: The results of research on the implementation of life cycle tools in Polish SMEs-Part 3: LCC-related aspects. Int. J. Life Cycle Assess. 2014, 19, 1119-1128. [CrossRef]

31. Andrzejczak, K.; Młyńczak, M.; Selech, J. Poisson-distributed failures in the predicting of the cost of corrective maintenance. Eksploat. Niezawodn.Maint. Reliab. 2018, 20, 602-609. [CrossRef]

32. Roy, S.; Kumar, S.; Gupta, R. Investigation and analysis of finger breakages in commercial crystalline silicon photovoltaic modules under standard thermal cycling test. Eng. Fail. Anal. 2019, 101, 309-319. [CrossRef] 
33. Ceran, B.; Orłowska, A. The Impact of Power Source Performance Decrease in a PV/WT/FC Hybrid Power Generation System on the Result of a Multi-Criteria Analysis of Load Distribution. Energies 2019, 12, 3453. [CrossRef]

34. Song, Z.; Le, J.; Whisler, D.; Kim, H. Skin-stringer interface failure investigation of stringer-stiffened curved composite panels under hail ice impact. Int. J. Impact Eng. 2018, 122, 439-450. [CrossRef]

35. Cha, H.; Bhang, B.; Park, S.; Choi, J.; Ahn, H. Power Prediction of Bifacial Si PV Module with Different Reflection Conditions on Rooftop. Appl. Sci. 2018, 8, 1752. [CrossRef]

36. Beinert, A.J.; Büchler, A.; Romer, P.; Haueisen, V.; Rendler, L.C.; Schubert, M.C.; Heinrich, M.; Aktaa, J.; Eitner, U. Enabling the measurement of thermomechanical stress in solar cells and PV modules by confocal micro-Raman spectroscopy. Sol. Energy Mater. Sol. Cells 2019, 193, 351-360. [CrossRef]

37. Boumaaraf, B.; Boumaaraf, H.; Slimani, M.E.-A.; Tchoketch_Kebir, S.; Ait-cheikh, M.S.; Touafek, K. Performance evaluation of a locally modified PV module to a PV/T solar collector under climatic conditions of semi-arid region. Math. Comput. Simul. 2020, 167, 135-154. [CrossRef]

38. Ozden, T.; Carr, A.J.; Geerligs, B.L.; Turan, R.; Akinoglu, B.G. One-year performance evaluation of two newly developed back-contact solar modules in two different climates. Renew. Energy 2020, 145, 557-568. [CrossRef]

39. Devadhas, G.G. Design and development of new control technique for standalone PV system. Microprocess. Microsyst. 2020, 72, 102888.

40. Orioli, A. An accurate one-diode model suited to represent the current-voltage characteristics of crystalline and thin-film photovoltaic modules. Renew. Energy 2020, 145, 725-743. [CrossRef]

41. Thormeyer, C.; Sasse, J.-P.; Trutnevyte, E. Spatially-explicit models should consider real-world diffusion of renewable electricity: Solar PV example in Switzerland. Renew. Energy 2020, 145, 363-374. [CrossRef]

42. Fathabadi, H. Novel solar-powered photovoltaic/thermoelectric hybrid power source. Renew. Energy 2020, 146, 426-434. [CrossRef]

43. Jendoubi, A.; Tlili, F.; Bacha, F. Sliding mode control for a grid connected PV-system using interpolation polynomial MPPT approach. Math. Comput. Simul. 2020, 167, 202-218. [CrossRef]

44. Gürtürk, M.; Benli, H.; Ertürk, N.K. Determination of the effects of temperature changes on solar glass used in photovoltaic modules. Renew. Energy 2020, 145, 711-724. [CrossRef]

45. Liu, D.; Sun, Y.; Wilson, R.; Wu, Y. Comprehensive evaluation of window-integrated semi-transparent PV for building daylight performance. Renew. Energy 2020, 145, 1399-1411. [CrossRef]

46. Mundaca, L.; Samahita, M. What drives home solar PV uptake? Subsidies, peer effects and visibility in Sweden. Energy Res. Soc. Sci. 2020, 60, 101319. [CrossRef]

47. Klugmann-Radziemska, E.; Kuczyńska-Łażewska, A. The use of recycled semiconductor material in crystalline silicon photovoltaic modules production-A life cycle assessment of environmental impacts. Sol. Energy Mater. Sol. Cells 2020, 205, 110259. [CrossRef]

48. Castro, L.M.; Rodríguez-Rodríguez, J.R.; Martin-del-Campo, C. Modelling of PV systems as distributed energy resources for steady-state power flow studies. Int. J. Electr. Power Energy Syst. 2020, 115, 105505. [CrossRef]

49. Manohar, M.; Koley, E.; Ghosh, S.; Mohanta, D.K.; Bansal, R.C. Spatio-temporal information based protection scheme for PV integrated microgrid under solar irradiance intermittency using deep convolutional neural network. Int. J. Electr. Power Energy Syst. 2020, 116, 105576. [CrossRef]

50. Tsai, C.-Y.; Tsai, C.-Y. See-through, light-through, and color modules for large-area tandem amorphous/microcrystalline silicon thin-film solar modules: Technology development and practical considerations for building-integrated photovoltaic applications. Renew. Energy 2020, 145, 2637-2646. [CrossRef]

51. Obiwulu, A.U.; Chendo, M.A.C.; Erusiafe, N.; Nwokolo, S.C. Implicit meteorological parameter-based empirical models for estimating back temperature solar modules under varying tilt-angles in Lagos, Nigeria. Renew. Energy 2020, 145, 442-457. [CrossRef]

52. Hassan, A.; Wahab, A.; Qasim, M.A.; Janjua, M.M.; Ali, M.A.; Ali, H.M.; Jadoon, T.R.; Ali, E.; Raza, A.; Javaid, N. Thermal management and uniform temperature regulation of photovoltaic modules using hybrid phase change materials-nanofluids system. Renew. Energy 2020, 145, 282-293. [CrossRef]

53. Al Garni, H.Z.; Awasthi, A. A Monte Carlo approach applied to sensitivity analysis of criteria impacts on solar PV site selection. In Handbook of Probabilistic Models; Elsevier: Oxford, UK, 2020; pp. 489-504; ISBN 978-0-12-816514-0. 
54. Singh, P.; Rajesh, B.; Bishnoi, S.; Swati, G.; Jaiswal, V.V.; Shanker, V.; Haranath, D. Optimization of processing parameters for designing an efficient AC driven powder electroluminescent device. Ceram. Int. 2016, 42, 17016-17022. [CrossRef]

55. Lin, K.; Lee, Y.-H.; Huang, W.-Y.; Chen, G.; Kuo, Y.-W.; Wang, L.-K.; Yang, S.-Y. Detection of soldering induced damages on crystalline silicon solar modules fabricated by hot-air soldering method. Renew. Energy 2015, 83, 749-758. [CrossRef]

56. Theis, D.; Oppolzer, H.; Ebbinghaus, G.; Schild, S. Cross-sectional transmission electron microscopy of electroluminescent thin films fabricated by various deposition methods. J. Cryst. Growth 1983, 63, 47-57. [CrossRef]

57. Lee, Y.; Tay, A.A.O. Stress Analysis of Silicon Wafer-Based Photovoltaic Modules Under IEC 61215 Mechanical Load Test. Energy Procedia 2013, 33, 265-271. [CrossRef]

58. Hülsmann, P.; Weiss, K.-A. Simulation of water ingress into PV-modules: IEC-testing versus outdoor exposure. Sol. Energy 2015, 115, 347-353. [CrossRef]

59. Hsu, S.-T.; Lin, W.-Y.; Wu, S.-J. Environmental Factors for Non-uniform Dynamic Mechanical Load Test due to Wind Actions on Photovoltaic Modules. Energy Procedia 2018, 150, 50-57. [CrossRef]

60. Fowler, S. Accelerated Environmental Chambers and Testing of PV Modules. In Durability and Reliability of Polymers and Other Materials in Photovoltaic Modules; Elsevier: Oxford, UK, 2019; pp. 257-277; ISBN 978-0-12-811545-9.

(C) 2019 by the authors. Licensee MDPI, Basel, Switzerland. This article is an open access article distributed under the terms and conditions of the Creative Commons Attribution (CC BY) license (http://creativecommons.org/licenses/by/4.0/). 